\title{
Statyba
}

\section{ON THE QUESTION OF THERMAL EQUILIBRIUM OF WINDOWS AND WALLS}

\section{A. Kedys \& V. Barkauskas}

To cite this article: A. Kedys \& V. Barkauskas (1999) ON THE QUESTION OF THERMAL EQUILIBRIUM OF WINDOWS AND WALLS, Statyba, 5:3, 229-232, DOI: 10.1080/13921525.1999.10531467

To link to this article: https://doi.org/10.1080/13921525.1999.10531467

曲 Published online: 26 Jul 2012.

Submit your article to this journal $\pi$

III Article views: 40 


\section{ON THE QUESTION OF THERMAL EQUILIBRIUM OF WINDOWS AND WALLS}

\section{A. Kedys, V. Barkauskas}

\section{Introduction}

An urgent problem of today is to diminish building heat losses through windows. Heat transmission through windows is strictly regulated, but not always evaluated with sufficient precision. The larger the difference between windows and other partitions, for example, in wall thermal resistance, the smaller is the precision with which real heat losses deprived through partitions with windows may be evaluated $[1,2]$. This work is based on thermal physics criterion relations and tries to show that usual calculation methods of heat losses through windows have their own application limits and must be defined more precisely.

\section{Methods}

The work is based on the criterion relations of heat transmission through partitions, used in thermal physics and on the results of many year tests of heat losses through windows.

\section{Results and their discussion}

Evaluating the distinctive heat losses $H_{a}$ at the enclosure with windows and walls, the following formula is used in calculations:

$$
H_{a}=\sum H_{s}+\sum H_{l}=\sum U_{s} A_{s}+\sum U_{l} A_{l}, \mathrm{~W} / \mathrm{K} ;(1)
$$
where:

$H$ - distinctive heat losses $\mathrm{W} / \mathrm{K}$;

$U$ - thermal transmission coefficient $\mathrm{W} /\left(\mathrm{m}^{2} \cdot \mathrm{K}\right)$;

$a, s, l$ - respectively indices of partition, walls and windows.

The formula is based on the presumption, that heat flow from the inside through the partition is uniform (2a) and stationary (2b):

$$
\frac{\partial \theta}{\partial t}=a \frac{\partial^{2} \theta}{\partial x^{2}} \quad \frac{\partial^{2} \theta}{\partial x^{2}}=0 ;
$$

$(2 \mathrm{a}$ and $2 \mathrm{~b})$

where:

$$
\theta \text { - temperature, } \mathrm{C}^{\mathrm{o}}
$$

$a$ - temperature conductivity coefficient $\mathrm{m}^{2} / \mathrm{s}$

$t$ - time.

In simplified $H_{a}$ calculations, according to formula (1) the excesses of two dimension temperature field are not evaluated at aperture edges or at the not uniform construction of doorposts, frames or glazed part or they are calculated as corrections of parameter values. It is supposed that the influence of window on the temperature distribution of internal wall surface equals half of the thickness [3] of the wall and heat flow is perpendicular to the internal surface of partitions (Fig 1, Table 1):

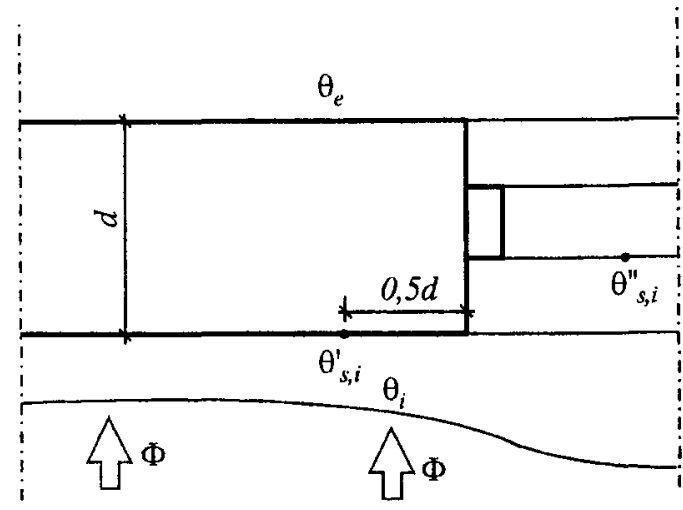

Fig 1. Characteristic points of partition (wails and windows) thermal state in calculating according to formula 1.

Table 1. The values of thermal behaviour parameters for external enclosures

\begin{tabular}{|c|c|c|c|}
\hline $\begin{array}{c}\text { Wall thermal } \\
\text { resistance } R_{s}, \\
\mathrm{~m}^{2} \cdot \mathrm{K} / \mathrm{W}\end{array}$ & $\begin{array}{c}\text { Temperature of } \\
\text { inside wall } \\
\text { surface } \theta_{s, p}{ }^{\circ} \mathrm{C}\end{array}$ & $\begin{array}{c}\text { Temperature } \\
\text { difference } \\
\left(\theta_{i}-\theta_{e}\right),{ }^{\circ} \mathrm{C}\end{array}$ & $\begin{array}{c}\text { Thermal } \\
\text { equilibrium } \\
\text { criterion } \\
U_{s} / U_{t}\end{array}$ \\
\hline 1 & 15,4 & 8,5 & 0,350 \\
\hline 2 & 17,7 & 10,8 & 0,175 \\
\hline 4 & 18,9 & 12,0 & 0,008 \\
\hline 6 & 19,2 & 12,3 & 0,058 \\
\hline 8 & 19,3 & 12,4 & 0,044 \\
\hline 10 & 19,4 & 12,5 & 0,035 \\
\hline
\end{tabular}

where:

$\Phi$ - heat flow, W; 
$d, e, I, s$ - thickness, external, internal and surface indices.

While calculating we presume that window thermal resistance $R_{l}=0,35 \mathrm{~m}^{2} \cdot \mathrm{K} / \mathrm{W}$ (const), window internal surface temperature $\theta^{\prime \prime}{ }_{s_{i}}=6,9^{\circ} \mathrm{C}$ (const), outside temperature $\theta_{e}=-20^{\circ} \mathrm{C}$, inside temperature $\theta_{i}=20^{\circ} \mathrm{C}$.

We can see from Fig 1 that when wall thermal resistance increases and window thermal resistance is stable, the difference of window internal surface temperatures comes closer to a constant and thermal equilibrium criterion $U_{i} / U_{1}$ [4] comes closer to zero. It shows that temperature field distorts when thermal equilibrium criterion decreases (Fig 2), then distinctive heat losses $H_{a}$ of enclosure from some moment can no longer be calculated according to formula (1).

It is known that heat conduction through partition with temperature difference $\Delta \theta=\theta_{i}-\theta_{c}$ proceeds according to the regularities of thermal conductivity and free convection. This conduction may be expressed in criterion equation [4]:

$$
N u_{x}=0,0295\left(G r_{x}\right)^{2 / 5} \cdot \operatorname{Pr}^{7 / 5}\left[1+0,494 \operatorname{Pr}^{2 / 3}\right]^{-2 / 5} \text {; }
$$

where:

$N u$ - Nuselt criterion $N u=\frac{h l}{\lambda}$;

$G r$ - Grasgof criterion $G r=\frac{\beta q l^{3}}{\gamma^{2}} \Delta \theta$;

$\operatorname{Pr}$ - Prandley criterion $\operatorname{Pr}=\frac{\gamma}{a}$ $h$ - criterion of heat trasmission by convection;

l - length;

$q$ - acceleration of terrestrial gravitation;

$\beta$ - gas volumetric expansion coefficient;

$\gamma$ - weather slough coefficient;

$\lambda$ - weather thermal conductivity coefficient;

$a$ - temperature conductivity coefficient.

Using the experimental data (3) the equation was simplified as follows [4]:

$$
N u=B(G r \cdot P r)^{n} \text {. }
$$

The constants " $B$ " and " $n$ " are fixed by experiment and given in Table 2 .

Table 2. Experimental values of quantities $B$ and $n$

\begin{tabular}{|c|c|c|}
\hline$(G r \cdot P r)$ & $B$ & $n$ \\
\hline $1 \cdot 10^{-3}-5 \cdot 10^{2}$ & 1,18 & $1 / 8$ \\
\hline $5 \cdot 10^{2}-2 \cdot 10^{7}$ & 0,54 & $1 / 4$ \\
\hline $2 \cdot 10^{7}-1 \cdot 10^{13}$ & 0,135 & $1 / 3$ \\
\hline
\end{tabular}

It is determined, that if $(G r \cdot P r)<1$, then Nuselt criterion is a constant: $N u=0,5$ [4] and thermal transmission goes on only by thermal conductivity [3]. In that case the convection heat flow constituent changes its direction to the lower potential (to the window) and flows around the wall surface until point $x_{1}$ (Fig 2) parallel to that surface. The simplified scheme of such heat flow distribution is shown in Fig 3.

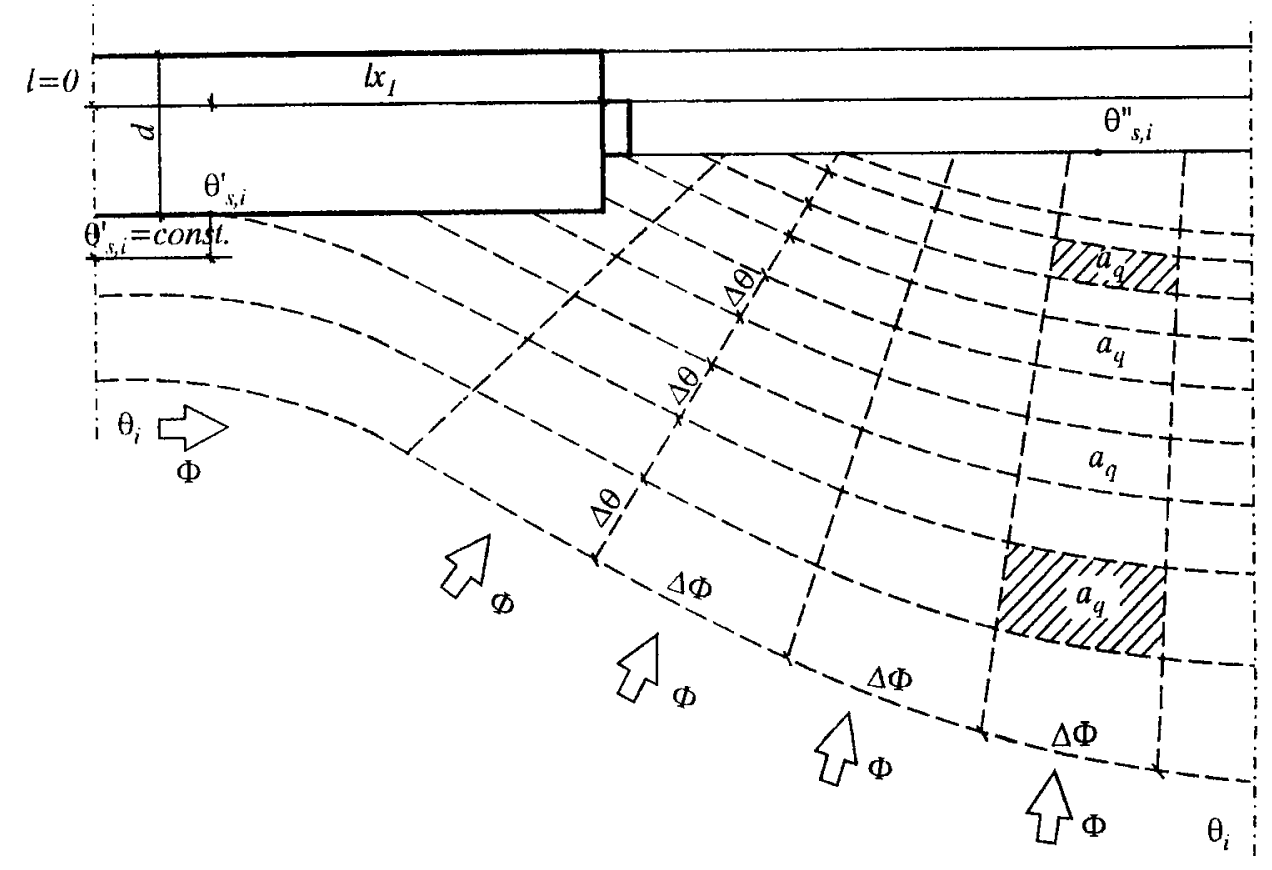

Fig 2. The distortion scheme of temperature field while thermal equilibrium criterion $U_{s} / U_{l}$ decreases 


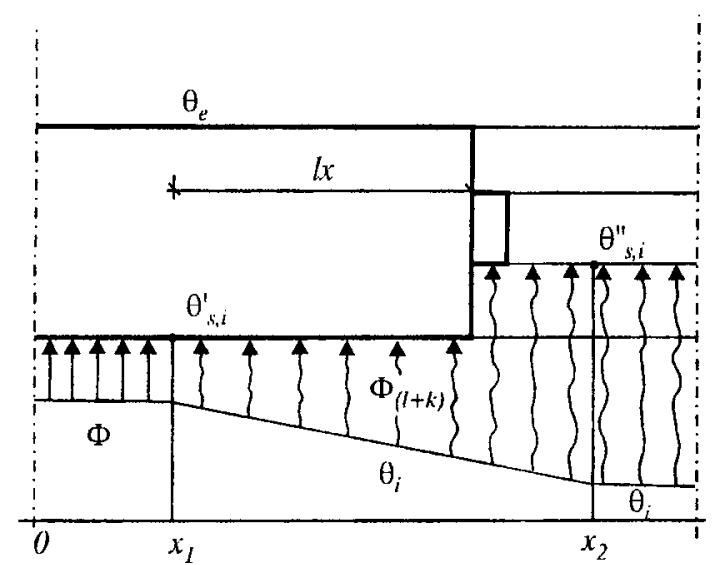

Fig 3. The scheme of heat flow distribution into "conductivity" and convection + conductivity" consituents

According to the scheme of Fig 3 three heat transmission spheres are distinguished:

1. From 0 to $x_{1}$ - heat exchange by conductivity in uniform system;

2. From $x_{1}$ to $x_{2}$ - heat exchange proceeds by convection and conductivity in two dimensional system;

3. From $x_{2}$ and further - heat exchange proceeds by convection and conductivity in uniform system.

The scheme given in Fig 2 may be explained as follows: the lines of temperature $(\theta)$ and heat flow ( $\Phi)$ restrict the temperature fields $a_{\text {il }}$ of limited size, where heat flow density increase is $\Delta \Phi_{a_{i}}=\Delta \theta \cdot \Delta \Phi$. It is supposed that heat flow density increase $\Delta \Phi$ equals to the chosen scale of temperature differences. Then $\Delta \theta=\Delta \Phi$. Between the two isolines of heat flows, drawn according to the chosen scale, imaginary heat flow "chanels" are made, where heat flow density $q$, $\mathrm{W} / \mathrm{m}^{2}$ increases when it comes closer to the window and the area $a_{q}$ of determined window decreases. Then heat density remains constant in every decreased $a_{q}$ field.

If we mark the number of intervals of temperature isolines by symbol $N_{\theta}$, the density increase of heat flow through the channel is:

$$
\Delta q=\frac{h_{k}}{N_{\theta}}\left(\theta_{1}-\theta_{2}\right), \mathrm{W} / \mathrm{m}^{2}
$$

where:

$h_{k}$ - the coefficient of heat transmission by convection, $W /\left(m^{2} \cdot K\right)$.

If we choose the intervals of heat flow channels according to the conditions $\Delta \theta=\Delta \Phi$, and mark their areas by $N_{\beta}, \mathrm{m}^{2}$, we find the total heat stream in sphere $x_{2} \rightarrow$ by expression:

$$
\Phi_{\left(x_{1} \rightarrow\right)}=\frac{N_{\Phi}}{N_{\theta}} \cdot h_{k}\left(\theta_{1}-\theta_{2}\right), \mathrm{W} ;
$$

and in the sphere $x_{1}-x_{2}$ :

$$
\Phi_{\left(x_{1}-x_{2}\right)}=\frac{N_{\Phi}}{N_{\theta}} \cdot h_{k}\left(\frac{\theta_{1}-\theta_{2}}{2}\right), \mathrm{W} \text {. }
$$

The distance $l_{(0-x)}$, where heat transmission goes on by thermal conductivity is found by:

$$
l_{\left(0-x_{1}\right)} \geq \frac{0,5 \lambda}{h_{k}}, \mathrm{~m} \text {. }
$$

We call the thermal equilibrium of windows and walls the case when formula (1) may be used for calculation of distinctive heat losses, it may be approximately evaluated according to thermal equilibrium criterion $U_{s} / U_{l}$ if:

$$
\frac{U_{s}}{U_{l}}>0,1
$$

Example: The thermal resistance $R_{s}=4 \mathrm{~m}^{2} \cdot \mathrm{K} / \mathrm{W}$ $\left(U_{s}=0,25 \mathrm{~W} / \mathrm{m}^{2} \cdot \mathrm{K}\right)$ of constructed wall. We obtain the minimal permissible thermal resistance $R$, of a window or maximal thermal conductivity coefficient $U_{l}$. It will satisfy the requirements of minimally accepted ratio (9).

$$
U_{l} \leq \frac{0,25}{0,1} \leq 2,5 \quad \mathrm{~W} / \mathrm{m}^{2} \cdot \mathrm{K}
$$

If these conditions are not satisfied, the value miscount of calculated distinctive heat losses will grow in proportion to the resistance ratio growth of walls and windows.

\section{Conclusions}

1. If the differences of window and wall thermal resistence are great, the used calculation method does not give results having one meaning.

2. On the base of heat exchange criterion ratio, we can approximately diffuse heat flow from inside enclosure to the components of "thermal conductivity" and "thermal conductivity + convection".

3. The diffusion of heat flow enables to deter- 
mine the permissible ratio of window and wall thermal resistance. Generally, when wall thermal resistance is increased from some particular moment, window thermal resistance must be increased respectively too.

\section{References}

1. A. Kedys, V. Barkauskas. Langai ir langeliai // Statyba ir architektūra, 1992. Nr. 9. p. 12-13.

2. А. М. Шкловер и др. Основы строительной теплофизики жильх и обшественных зданий. Москва: Госстройиздат. 1956. $350 \mathrm{c}$.

3. Б. М. Богословский. Тепловой режим здания. Москва: Стройиздат, 1974. $248 \mathrm{c}$.

4. А. В. Лыков. Теоретические основы строительной теплофизики. Минск. $1961.519 \mathrm{c}$.

Iteikta 19990603

\section{LANGU IR SIENU ŠILUMINĖS PUSIAUSVYROS KLAUSIMU}

\section{A. Kedys, V. Barkauskas}

\section{$\mathrm{S}$ a n t r a u k a}

Skaičiuojant savituosius šilumos nuostolius laikoma kad šlumos srautas yra vienamatis $i$ visus atitvaroje esančius elementus (langus, sienas). Ši prielaida praktiškai teisinga, kol langų ir sienu izoliacinè galia ne itin skiriasi. Didejant šiam skirtumui šilumos srautas iškrypsta ir pradeda tekèti mažiausio pasipriešinimo keliu.

Is 1 pav. matyti, kad sienos šiluminei varžai didejant, o lango - nekintant, lango vidaus paviršiaus temperatūru skirtumas artèja prie pastoviojo dydžio, o šiluminès pusiausvyros kriterijus $U / U$, [4] arteja prie nulio. Tai rodo, kad temperatūrinis laukas, mažejant šiluminès pusiausvyros kriterijui, kreiveja ( 2 pav.) ir tuomet atitvaros savitieji šilumos nuostoliai $H_{a}$ nuo tam tikro momento negali būti skaičiuojami pagal 1 formulę.

Nustatyta [4], kad tuo atveju, kai Nuselto kriterijus $N u=B(G r \cdot P r)^{n}=0,5$, šilumos perdava vyksta tik šilumos laidumu ir konvekcine silumos srauto dedamoji keicia krypti žemesnio potencialo link (i langa), o sienos paviršių iki taško $x_{1}$ (2 pav.) apteka lygiagrečiai tam paviršiui.

Langu ir sienų šilumine pusiausvyra pavadinę atveji pagal kuri savitiesiems šilumos nuostoliams skaiciuoti galima taikyti 1 formulę, ją galima apytikriai ivertinti pagal šiluminès pusiausvyros kriteriju $U / U_{l}$ su sąlyga, kad $U / U,>0,1$, antraip savitiesiems šilumos nuostoliams apskaičiuoti šis metodas netinka.

Algimantas KEDYS. Doctor. Institute of Architecture and Construction, Building Thermal Physics Laboratory. Tunelio 60,3035 Kaunas, Lithuania.

Author and co-author of more than 50 reports and papers, including publications "The decrease of thermal transmittance values for windows" and General technical requirements for windows. Research interests: energy savings in buildings, problems of improvement in windows operating properties.

Vytautas BARKAUSKAS. Doctor, Merited Architect. Institute of Architecture and Construction. Tunelio 60, 3035 Kaunas, Lithuania.

Author of more than 50 reports. Co-author of 3 monographs, 2 study guides and 3 Lithuanian Building Codes. He has designed and built a number of dwelling houses and some building renovation projects. Author of architectural acoustic design for a number of public buildings. Research interests: technical progress in architecture, thermal building physics and durability forecast of external finish layers. 